\title{
What Caused the Great Recession?
}

\author{
Stefan Homburg \\ Hannover Economic Papers (HEP) No. 536 \\ ISSN 0949-9962 \\ Published: Review of Economics 66 (1), pp. 1-12. \\ doi:10.1515/roe-2015-0102
}

School of Economics and Management, Leibniz University Hannover, Germany. Phone: +49 511 762-5633. Email: homburg@fiwi.uni-hannover.de.

Abstract: This paper examines five possible explanations for the Great Recession of 2008 and 2009, using data for the United States and the eurozone. Of these five hypotheses, four are not supported by the data, while the fifth appears reasonable.

Keywords: Financial crisis; Great Recession; wealth effect; credit crunch; money demand; central bank.

JEL-Classification: E3, E4, G1 


\section{Introduction}

The financial crisis that preceded the Great Recession of 2008 and 2009 is fairly well understood. It was triggered by a housing bubble. When the bubble burst, collateral was wiped out, reducing ratings of both structured products and market participants and eventually resulting in large defaults and bailouts. Brunnermeier (2009) describes the events in detail.

The link, however, between the financial turmoil on one hand and the subsequent decline in real economic activity on the other is less clear. During the past few years, numerous explanations, in part only narratives, have been discussed. A consensus or at least a majority view about the way in which financial crises produce recessions has not yet emerged.

This paper contributes to answering the important question of how the financial crisis may have caused the Great Recession by conducting an empirical test of five possible explanations: i) An exceptional real shock, ii) a wealth effect, iii) a decrease in the money stock, iv) a credit crunch, and v) an increase in money demand. Each hypothesis has specific implications that are compared with data for the United States and the eurozone. The United States and the eurozone have been selected because they are the world's largest currency areas.

Figure 1 recollects the key feature of the Great Recession, namely, remarkable drops in nominal gross domestic product (GDP). Nominal GDP declined in 2008:IV in the United States and one quarter earlier in the eurozone. The retreat lasted until 2009:II in both cases. From 2008 to 2009, annual nominal GDP fell by 2.0 percent in the United States and by 3.5 percent in the eurozone. Though declines in real GDP have been more frequently observed, one has to go back to the 1930s in order to find a comparably strong reduction in nominal GDP.
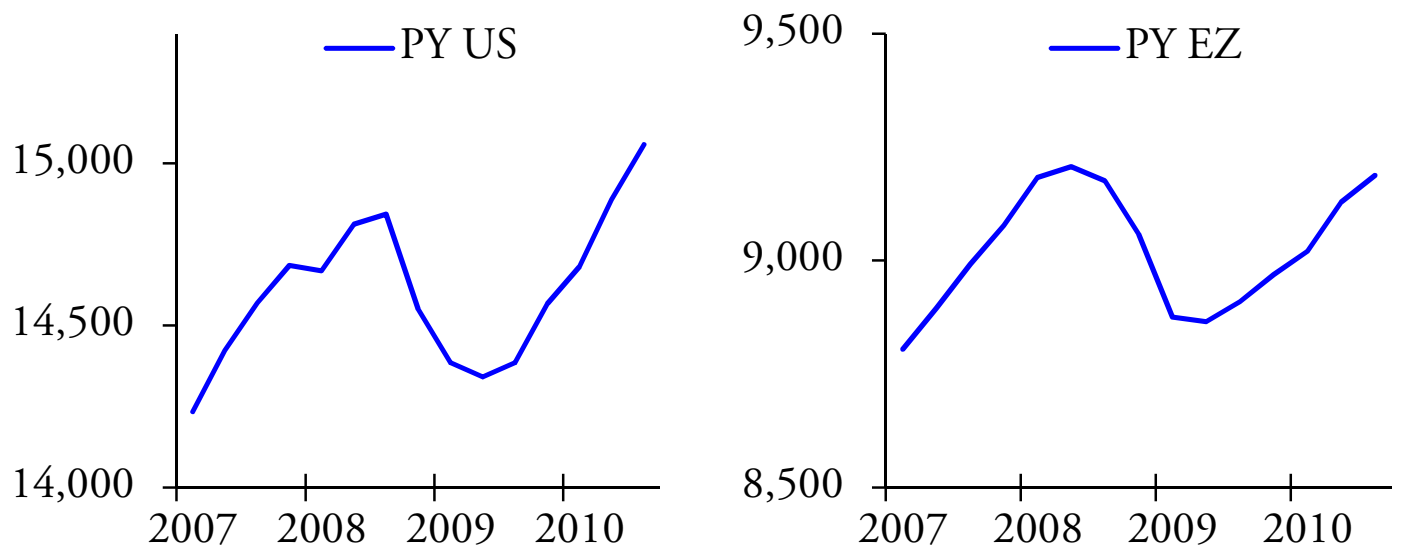

Figure 1. The left panel shows United States nominal GDP, annual rate, in bn dollars. The right panel shows eurozone nominal GDP, annual rate, in bn euros. Unless otherwise indicated, data presented in this study are quarterly and seasonally adjusted. 
Another remarkable feature of the Great Recession was the procyclical behavior of consumer prices. During 2008:IV and 2009:I, the recession not only reduced inflation rates but also depressed the levels of the consumer price indexes (CPI): Based on annualized quarter-on-quarter changes, the United States CPI fell by 8.9 and 2.7 percent, respectively, and the eurozone CPI fell by 1.1 and 2.7 percent.

The text below, which aims at developing a satisfactory account of these extraordinary events, is organized as follows. Section 2 outlines the methodology and relates the paper to the existing literature. It also introduces a minimal theoretical framework that is needed to discriminate between the competing hypotheses. Section 3 states each of the five aforementioned explanations for the Great Recession, checks their internal consistency, and compares them with the data. Section 4 concludes and presents a somewhat uneasy outlook.

\section{Theoretical Framework}

Current mainstream models (DSGE) derive the movements of economic aggregates from the decisions of perfectly rational agents optimizing utility over infinite horizons. All economic fluctuations result from disturbances that are both exogenous and unobservable. Many economists think that such an approach is unable to deliver a meaningful explanation for the Great Recession. Bernanke (2010:17) puts his critique somewhat mildly: "Economic models are useful only in the context for which they are designed. Most of the time, including during recessions, serious financial instability is not an issue. The standard models were designed for these non-crisis periods, and they have proven quite useful in that context." Ireland (2011), who adheres to the DSGE model, believes the Great Recession was caused by disturbances that were simply more enduring and intense than those in earlier times. Christiano, Eichenbaum and Trabandt (2014) try to rescue the standard approach by introducing additional unobservable disturbances. In this way it is possible to get a good fit, of course. However, introducing more unobservable variables amounts to implicit reasoning and yields neither economic intuition nor a falsifiable theory.

An examination of some key events of the financial crisis suggests that 2008 was not the right year for rational expectations. After the bankruptcy of Lehman Brothers on September 15, the bailout for AIG on September 16, and the introduction of the Troubled Asset Relief Program (TARP) with its strong signaling effect, IMF chief Strauss-Kahn saw the global financial system as being on the "brink of systemic meltdown”. An investment banker bought many acres of land-not as a profitable investment but because he wanted to be able to support his family with crops after the system's total collapse. After some rumors, a wealth manager walked secretly to his local ATM at midnight in order to check if banknotes were still available. Everybody remembers such stories which indicate that human behavior was more driven by panic than by due deliberation at that time.

The strategy followed in this paper follows Colander et al. (2008) who advocate an "engineering approach" to macroeconomics rather than a "scientific approach". The 
strategy is also in accordance with Alchian's (1950) methodology that sees optimization as the outcome of an evolutionary process. Because evolution takes time, one cannot expect people to adhere to accustomed optimization habits during a frenzy; nor can one expect stable time series allowing valid econometric inferences. Only a minimum of rationality is assumed here, namely, that market participants behave in accordance with their budget constraints.

The model portrays a closed economy inhabited by a finite set $\mathcal{A}$ of agents, such as households, nonfinancial corporations, commercial banks, a central bank, and government entities. Each agent $a \in \mathscr{A}$ chooses commodity demands $x_{a}^{d}$ and commodity supplies $y_{a}^{s}$ from a common finite commodity space. Denoting money prices as $p$, the inner products $p x_{a}^{d}$ and $p y_{a}^{s}$ represent the respective values of commodity demand and supply. In addition to acting in the markets for goods and services, each agent either wishes to hold money balances, denoted as $m_{a}^{d} \geq 0$, or makes such balances available to others, which is denoted as $m_{a}^{d}<0$. Money is understood here in the usual M1 sense; it comprises the value of coins, notes, and demand deposits outside the central bank. Agents that make money available to others are the central bank and the deposit banks. For them, money constitutes a liability; for the other agents it constitutes an asset.

Moreover, each agent plans to hold financial assets and liabilities other than money (e.g., bonds, loans, or stocks). The total value of these financial assets, denoted as $b_{a}^{d}$, is positive in the case of a net long position and negative otherwise. Finally, the government sets taxes and transfers, and $t_{a}$ denotes an agent's balance of tax and transfer payments (positive for the government or a welfare recipient, negative for a taxpayer). An agent's budget constraint-which is understood in an ex ante sense, not as a mere accounting identity—reads

$$
p x_{a}^{d}+\Delta m_{a}^{d}+\Delta b_{a}^{d}=p y_{a}^{s}+t_{a},
$$

where $\Delta m_{a}^{d}$ represents planned changes in money balances and $\Delta b_{a}^{d}$ represents planned changes in other financial assets. The budget constraint states that expenditure plus increase in net worth equals revenue from sales net of tax and transfer payments. Aggregates are denoted by capital letters:

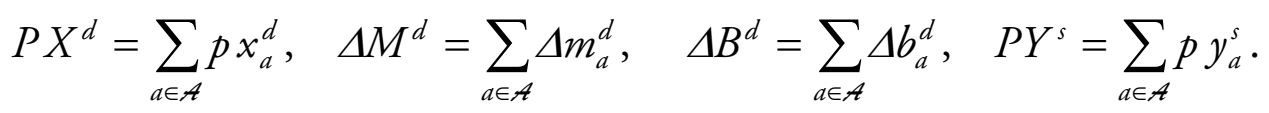

Summing the individual budget constraints over all agents and substituting the aggregate symbols yields a simple budget constraint for the economy as a whole, where tax and transfer payments net out:

$$
\left(P X^{d}-P Y^{s}\right)+\Delta M^{d}+\Delta B^{d}=0 .
$$

The overall budget constraint shows three excess demands that sum up to zero (Walras' Law). These are the excess demands for commodities, for money, and for bonds; the latter term is used generically for all financial assets except money. A key feature of the overall budget constraint is that it includes changes in money balances 
and treats them as an expenditure item. Such a representation is closely related to national accounting conventions and has a number of interesting implications. An excess commodity supply is only possible if there is an excess demand for money, for bonds, or for both. When one assumes realistically that prices in financial markets adjust quickly, at least compared with commodity prices, the excess demand for bonds can be expected to vanish at all times. This is true at least in the sense that a lasting positive excess demand for bonds appears highly implausible; no one has ever heard of potential bond buyers who could not get the desired bonds. Rationing is possible in credit markets but always affects the borrowers, not the lenders. Therefore, an excess commodity supply cannot be due to an excess bond demand but presupposes an excess money demand. In contrast to prices of bonds and other financial assets, the price of money cannot adjust because money is the unit of account and its price always equals unity. This observation entails a crucial difference between excess bond demands and excess money demands: While excess bond demands are eliminated within minutes (or milliseconds) via adjustments in asset prices and interest rates, an excess money demand, combined with an excess commodity demand of the opposite sign, can only be eliminated by adjustments in commodity prices that are possibly persistent and painful.

A final observation pertains to nonfinancial assets that do not enter the aggregate budget constraint. While a single agent can transform nonfinancial assets into goods and services, e.g., by selling his home, this is not possible for the economy as a whole. At the aggregate level, commodity expenditure $(P X)$ can only be financed by newly produced commodities $(P Y)$. When agent No. 1 sells a home or a car to agent No. 2, the former gets the money and the latter spends it, and there is no increase in aggregate purchasing power. The same principle holds true in the case of financial wealth because financial net worth is always zero in a closed economy (or in the world as a whole).

\section{The Competing Explanations}

Following these preliminary remarks, the five possible explanations for the Great Recession that were mentioned in the introduction are now compared.

\subsection{Real Shock}

Real business cycle theory is a good starting point because it dominated the literature for a substantial amount of time and is well-suited to prepare the ground for financial explanations in the broadest sense. The approach can be outlined by means of two equations. The first is the well-known Cambridge equation $M=k P Y$, which relates the money stock $(M)$ to money demand as a fraction $(k)$ of gross domestic product $(P Y)$. The second equation, $Y=A F$, determines real GDP as a product of a technology shock $A$ and a standard production function $F$. Kydland and Prescott (1990), who contributed to the popularity of real business cycle theory, called monetary shocks a "myth" and argued real economic activity was only driven by technology disturbances. The principal argument in favor of their theory was the finding 
that commodity prices $(P)$ and volumes $(Y)$, at least after seasonal adjustment and "filtering", were negatively correlated. In terms of the two equations, $P Y$ is fixed by stable monetary conditions, positive technology shocks push up $Y$ and reduce $P$, and negative shocks work in the opposite direction.

However, Kydland and Prescott (1990) were careful to state a positive correlation between prices and volumes during the depression of the 1930s. As noted in the introduction, the Great Recession was similar to the Great Depression in this important aspect: Prices and volumes plunged simultaneously. Such a procyclical price movement is completely in disagreement with real business cycle theory and points in the direction of a financial transmission channel.

\subsection{Wealth Effect}

The wealth effect explanation claims that the Great Recession was triggered by strong declines in the prices of homes, stocks and other assets. This argument comes in three versions which are discussed in increasing order of sophistication.

The first version of the wealth effect explanation asserts that a plunge in asset prices forces asset owners to reduce expenditures and thus depresses aggregate demand. This argument is a fallacy of composition (which may explain its popularity). The flaw lies in the exclusive focus on asset sellers and in the neglect to consider the corresponding effects on asset buyers. For example, a home owner whose home was worth $\$ 300,000$ before the crisis and who gets only $\$ 200,000$ after the crisis must reduce consumption by $\$ 100,000$. However, the home buyer saves the same amount and therefore can increase consumption by $\$ 100,000$. At the aggregate level, the two partial effects cancel out each other.

The second form of the wealth effect explanation argues that a decline in aggregate wealth may increase savings rates as people try to restore their previous wealth. Such an argument is used by Farmer (2012: 695), for example. It encounters two problems. Empirically, savings rates did not increase before or during the Great Recession. In the United States, gross saving as a percentage of GDP fell steadily from 18 percent in 2007:II to 14 percent in 2009:II. In the eurozone, the same figure fell from 23 percent in 2007:II to 19 percent in 2009:II. In both cases, saving rates decreased rather than increased. Moreover, from a theoretical point of view, there is no link between savings and economic activity. Increases in savings, if understood as increases in desired bond demand, induce immediate adjustments in interest rates which restore bond market equilibrium within minutes. A lasting excess demand for bonds that could induce a lasting excess supply in the commodity market via equation (3) has never been observed.

The third form of the wealth effect argument points to a zero lower bound (ZLB) on interest rates and questions the existence of an interior bond market equilibrium. To evaluate this argument, the left panel in figure 2 shows that the Fed lowered the federal funds rate almost to zero during the recession; it reduced this rate to 0.2 percent in December 2008. However, the rate for Fed overnight loans to commercial banks 
is not relevant for private savers and investors who base their decisions on, for example, corporate bond rates, government bond rates, or the conventional mortgage rate. As the left panel in figure 2 also makes clear, the AAA corporate bond rate did not approach zero during the recession but always stayed above four percent; government bond rates and the conventional mortgage rate both showed very similar patterns. The right panel in figure 2 pertains to the eurozone: While the main refinancing rate dropped sharply, but never fell below one percent, the interest rate for loans to nonfinancial corporations remained steadily above three percent.
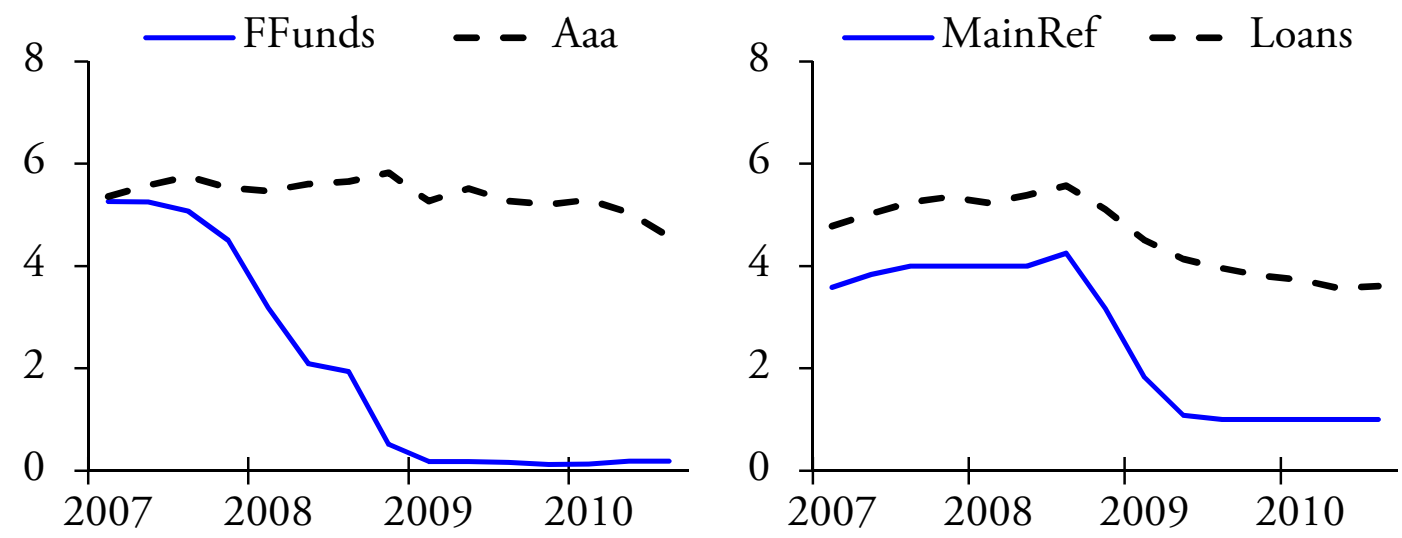

Figure 2. The left panel for the United States shows the federal funds rate (solid line) and the AAA corporate bond rate (broken line). The right panel for the eurozone shows the main refinancing rate (solid line) and the rate of loans to nonfinancial corporations (broken line). Data are monthly and in percent.

A ZLB problem in the sense of an excess supply in the bond markets did not exist in the United States or in the eurozone. Quite on the contrary, yields relevant for savers and investors remained strictly positive throughout the recession. Combining these findings with the preceding arguments shows that wealth effects cannot contribute to a coherent account of the Great Recession.

\subsection{Decrease in Money Stock}

In an often cited study, Friedman and Schwartz (1963) made a compelling case that the Fed contributed to the severity of the 1930s depression through its tight monetary policy. Indeed, the Fed, adhering to the rules of the gold standard, permitted a fall in the money stock M1 that lasted until 1934, when economic activity rebounded. In terms of equation (3), the causal explanation runs as follows: A decrease in the money stock induces an excess money demand $\left(\Delta M^{d}>0\right)$ and an excess commodity supply $\left(X^{d}<Y^{s}\right)$ if bond markets are permanently equilibrated by changes in interest rates $\left(\Delta B^{d}=0\right)$. As the Friedman and Schwartz hypothesis is widely accepted today, one may ask whether the Great Recession was similar in this respect, too.

Figure 3 offers a clear answer to this question. The United States money stock M1 rose steadily during the entire period under consideration. Its growth rate even accelerated markedly in the second half of 2008. Between 2008:II and 2009:II, the 
money stock grew by 17 percent. The eurozone shows a similar pattern: The growth of money stock M1 accelerated in the second half of 2008, and the money stock showed an overall increase of 10 percent between 2008:II and 2009:II, when the recession ended.
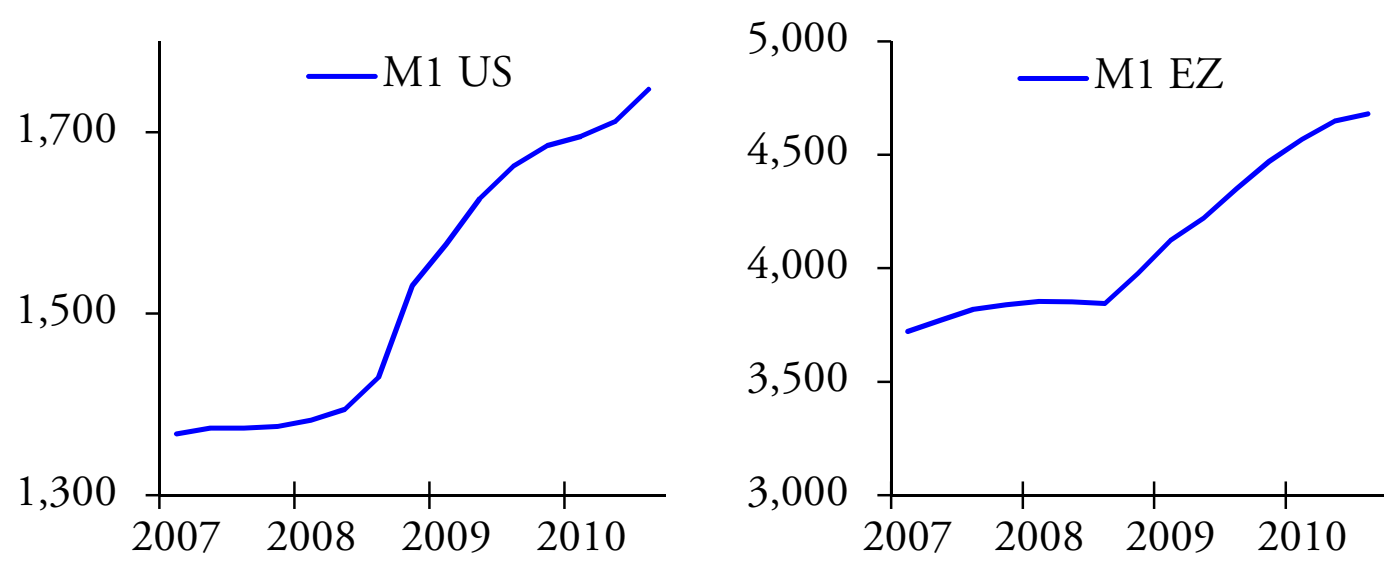

Figure 3. The left panel shows the United States money stock M1 in bn dollars. The right panel shows the eurozone money stock M1 in bn euros.

\subsection{Credit Crunch}

The credit crunch hypothesis is perhaps the most popular explanation for the emergence of the Great Recession. The idea is that if would-be home buyers and other investors cannot obtain financing, they will not be able to carry out their purchase plans and must revise them, which may contribute to a fall in commodity demand. Concerns about a credit crunch were omnipresent in the media at the end of 2008, but the following charts raise serious doubts about this explanation.
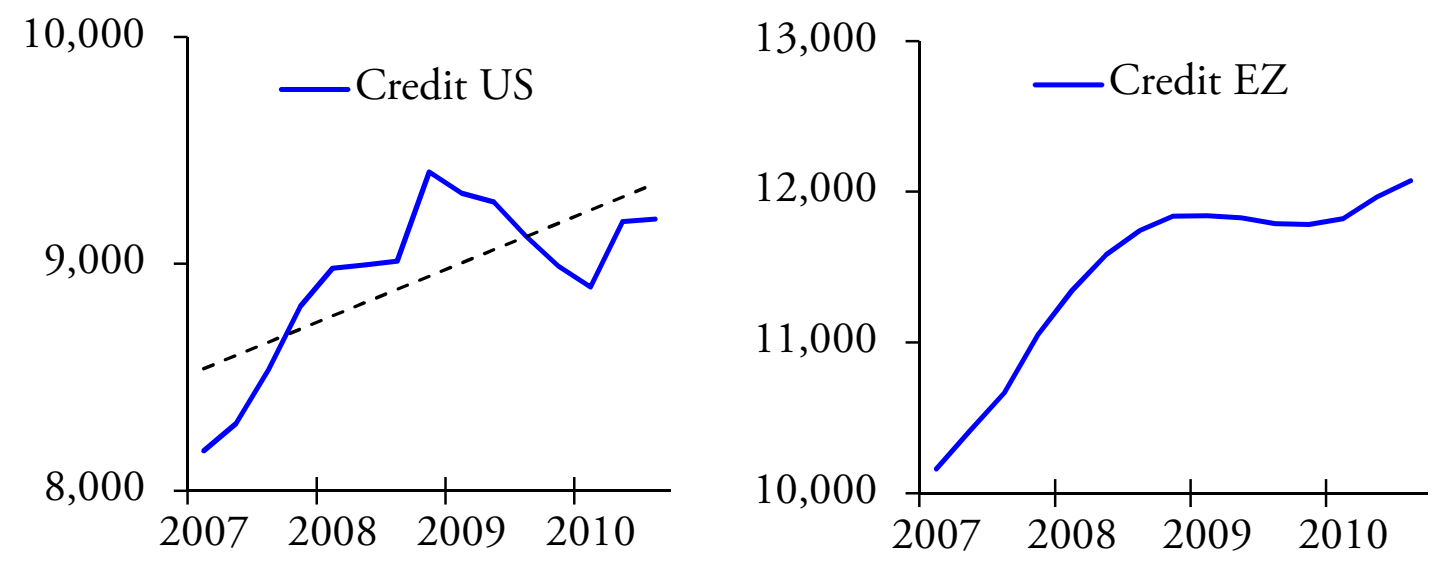

Figure 4. The left panel shows bank credit of United States commercial banks in bn dollars (solid line) and its linear trend over the considered period (broken line). The right panel shows eurozone MFI loans to non-MFIs in bn euros.

In the United States, it is true that the level of bank credit began to decline in 2009:I. However, this reduction seems to reflect the extraordinary increase that took 
place exactly during the second half of 2008, when the recession started. Ivashina and Scharfstein (2010:330) attribute the sharp rise in bank credit to the fact that bank customers drew on available credit lines in order to protect their liquidity. These authors see the subsequent moderate decrease in credit and deposits as an indication that perceived default probabilities declined after 2008.

In any case, considered over the entire recession period 2008:II to 2009:II, when real GDP decreased, United States bank credit rose from 8,996 to 9,275 bn dollars, and eurozone loans surged from 11,579 to 11,827 bn euros. There is no indication of a credit crunch at the aggregate level.

This result is in accordance with several case studies that find contractions in single markets or reductions in overall growth but no declines in aggregate credit levels. For the United States, Ivashina and Scharfstein (2010) investigate syndicated loans to large corporations. They find evidence that issuance of new such loans fell after 2007:II but also note (p. 326) that the total stock of commercial and industrial bank credit grew in the crisis year 2008. Considering equation (3) above, it is only the total stock that is relevant for aggregate performance, not whether it is composed of new or old loans. In two German case studies, Gern and Jannssen (2009) find no conclusive evidence for a credit crunch whereas Puri, Rocholl and Steffen (2011) detect an adverse effect on consumer loans made by certain savings banks but also ascertain strong growth in total bank lending. Using data for Portugal, Iyer et al. (2013) state that the growth rate of credit for nonfinancial firms declined during the crisis, but with positive annual growth rates exceeding 10 percent in every month between January 2007 and January 2009.

In sum, the hypothesis that decreases in nominal and real GDP levels resulted from diminished levels of bank credit is rejected by data for the United States and the eurozone. The popularity of the credit crunch explanation may again trace back to a fallacy of composition: While one can hardly deny that specific markets dried up during the financial crisis, such an occurrence has no direct implication for the aggregate credit level. For instance, mortgage credit was channeled through ABS conduits before the crisis and through more traditional channels (i.e., direct lending) afterwards. Such a redirection need not have an impact on the total credit volume.

\subsection{Increase in Money Demand}

The fifth and final explanation holds that the Great Recession and the plunge in nominal GDP, which was its outstanding characteristic, were caused by an increase in money demand. Assuming a constant money stock for the moment, an increase in money demand entails $\Delta M^{d}>0$ which, together with a bond market equilibrium $\left(B^{d}=0\right)$, implies an excess commodity supply $\left(X^{d}<Y^{s}\right)$. This follows directly from equation (3). The excess commodity supply brings down both commodity prices and volumes. While volumes may remain unaffected in the long run (money neutrality), there is a real effect in the short run because commodity prices do not adjust instantaneously. 
In order to examine this hypothesis, excess money demand is specified as the difference between desired money balances and a constant money stock:

$$
\Delta M^{d}=k P Y-\bar{M} .
$$

Nonbank agents wish to hold a fraction $(k)$ of nominal GDP in form of currency and deposits. This fraction, referred to as the Cambridge $k$ or as relative money demand, shows up empirically as the ratio of the money stock and nominal GDP. It need not stay constant over time. The key behavioral assumption is that agents wish to hold a specific fraction of nominal GDP in form of money. Increases in $k$ have no direct effect on the money stock because the latter is determined by central bank decisions to make reserves and currency available and by commercial bank decisions to grant loans and create demand deposits as a side-product. Therefore, the only effect of an increase in desired money balances is a decline in nominal GNP, brought about by reduced expenditure.

Figure 5 traces the Cambridge $k$ during the financial crisis and the recession. Both the left panel for the United States and the right panel for the eurozone show sharp increases in money demand. The jumps started simultaneously in autumn 2008 and lasted for roughly a year. Between 2008:II and 2009:II, money demand surged by 15 percent in the United States and by 14 percent in the eurozone. Such pronounced increases in money demand have no parallel in United States postwar history (nor, of course, in the short history of the eurozone). The reductions in nominal GDP were less strong because the increases in money stocks documented in section 3.3 cushioned the money demand shocks.
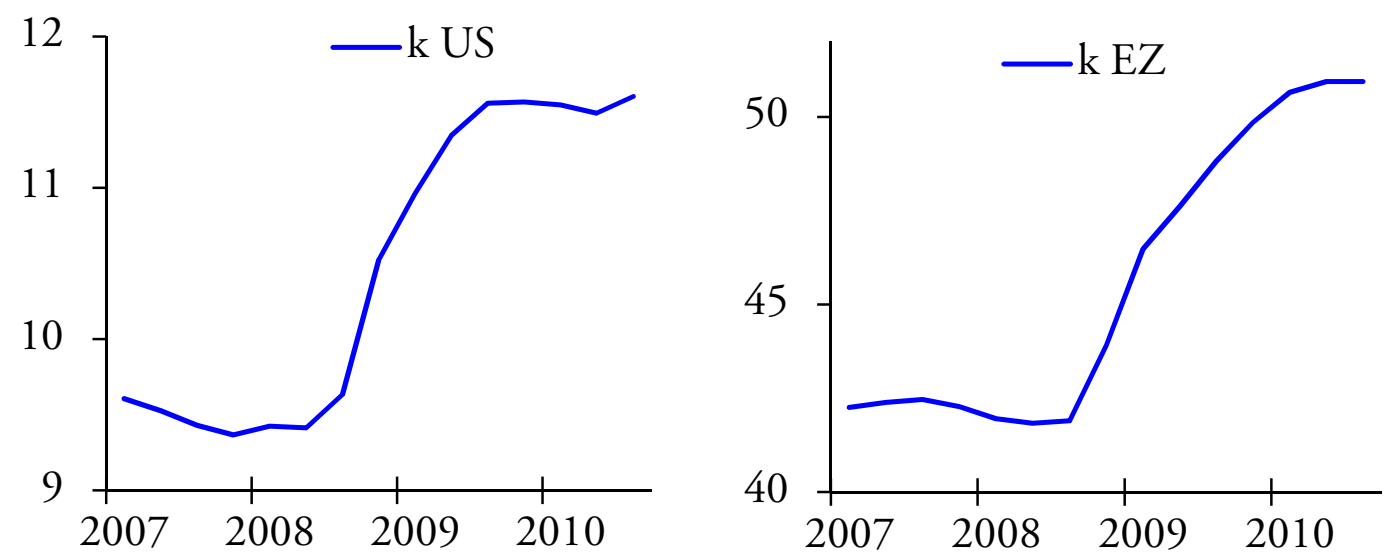

Figure 5. The left panel shows the ratio of United States M1 and nominal GDP as a percent. The right panel shows the ratio of eurozone M1 and nominal GDP as a percent.

The striking coincidence of the increases in United States and eurozone money demand raises the question of a possible common cause. Proceeding from the hypothesis that the increase reflected a panic, often circumscribed as "flight to quality", it seems natural to contrast the changes in $k$ with changes in an appropriate panic measure. The best known panic measure is the TED spread, the difference between 
three-month Eurodollar interbank loans (LIBOR) and the yield on three-month treasury bills. Because both underlyings are identical with respect to duration and denomination, the TED spread indicates perceived bank default probabilities.

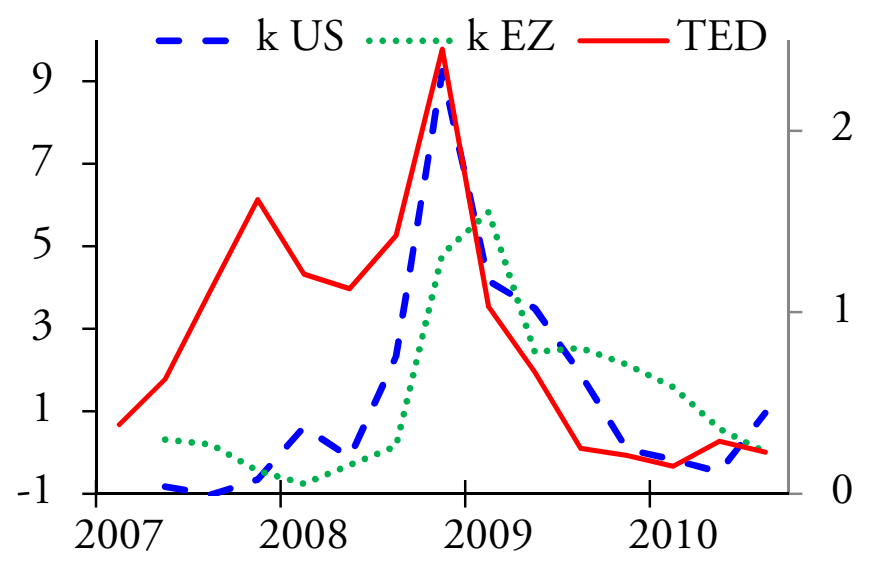

Figure 6. The panel shows the TED spread (solid line, right scale), the percentage increase in $k$ for the United States (broken line, left scale), and the percentage increase in $k$ for the eurozone (dotted line, left scale). The growth rates are quarter-onquarter changes.

Figure 6 suggests that panic was indeed the driving force behind the sudden increase in money demand: The TED spread and the growth in United States $k$ peaked in the fourth quarter of 2008; the growth in eurozone $k$ peaked one quarter later. Toward the end of the recession, all three measures declined to their original values. The resulting excess money demand was not, as is often implicitly assumed, mirrored by an excess bond supply but by an excess commodity supply which reinforced the ongoing contraction and turned overall economic performance from bad to worse.

\section{Conclusion}

This paper has examined five possible explanations for the Great Recession of 2008 and 2009. Four of these hypotheses were found to be unconvincing: Real business shocks are contradicted by procyclical price changes. Wealth effects do not present a coherent story and contrast with declines in savings rates. A fall in money stocks can also be ruled out because money stocks rose sharply both in the United States and in the eurozone. The same objection must be raised against the credit crunch hypothesis: At the aggregate level, bank credit surged rather than plunged before and during the recession which means that the recession cannot be attributed to a credit crunch.

Only the fifth candidate, a sudden rise in money demand, is in agreement with the data. As demonstrated in the last subsection, market panic as measured by the TED spread induced precautionary hoarding which, in turn, brought down nominal GDP in the United States and the eurozone. The increases in money demand, amounting to 14-15 percent, were cushioned by strong monetary expansions. Con- 
sidering that United States and eurozone banks held almost no excess reserves until August 2008, the monetary expansion was made possible by central bank decisions to boost the monetary base. In light of the present analysis, these policy decisions helped avoiding an even stronger recession.

Excess bank reserves have been essentially zero in the United States since the end of WWII and in the eurozone since its inception. This has now changed, and the change is perplexing. Since September 2009, excess bank reserves rose to startling levels in the United States and the eurozone, often exceeding 10 percent of GDP. Bank credit and deposits, however, have not kept up with this growth, which means that banks are currently not restricted by reserve requirements but subject to other restrictions, such as regulation or lack of good collateral. This has an uneasy implication: Another financial crisis, inducing a further sudden rise in money demand, could not be addressed by the central banks in the way they tackled the Great Recession. Rather, the outcome could be similar to the events in the 1930s.

\section{Data Appendix}

Data were retrieved in August 2014. Figure 1 shows series GDP from FRED and namq_gdp_c from Eurostat. Figure 2 shows FEDFUNDS and AAA from FRED, FM.B.U2.EUR.4F.KR.MRR_FR.LEV and MIR.M.U2.B.A2A.J.R.A.2240.EUR.N from the European Central Bank. Figure 3 shows M1SL from FRED and BSI.M.U2.Y.V.M10.X.1.U2.2300.Z01.E from the European Central Bank. Figure 4 shows series TOTBKCR from FRED and BSI.M.U2.N.U.A20.A.1.U2.2000.Z01.E from the European Central Bank. Figure 5 shows the ratios of M1 and GDP, for the United States and the eurozone. Figure 6 shows the growth rates of these ratios and series TEDRATE from FRED.

The corresponding web addresses are research.stlouisfed.org/fred2/ for FRED, epp.eurostat.ec.europa.eu/portal/page/portal/statistics/search_database for Eurostat, and sdw.ecb.europa.eu/ for the European Central Bank. 


\section{References}

Alchian, A. A. (1950) Uncertainty, Evolution, and Economic Theory. Journal of Political Economy 58: 211-221.

Bernanke, B. (2010) On the Implications of the Financial Crisis for Economics. Conference speech, Princeton University, Princeton, New Jersey.

Brunnermeier, M. K. (2009) Deciphering the Liquidity and Credit Crunch 20082009. Journal of Economic Perspectives 23: 77-100.

Christiano, L. J., M. S. Eichenbaum and M. Trabandt (2014) Understanding the Great Recession. Board of Governors of the Federal Reserve System International Finance Discussion papers no. 1107.

Colander, D., P. Howitt, A. Kirman, A. Leijonhufvud and P. Mehrling (2008) Beyond DSGE Models: Toward an Empirically Based Macroeconomics. American Economic Review (PP) 98: 236-240.

Farmer, R. E. A. (2012) The Stock Market Crash of 2008 Caused the Great Recession. Journal of Economic Dynamics and Control 36: 693-707.

Friedman, M. and A. J. Schwartz (1963) A Monetary History of the United States, 1867-1960. Princeton: Princeton University Press.

Gern, K.-J. and N. Jannsen (2009) Do We Face a Credit Crunch? Kiel Policy Brief no. 15.

Ireland, P. N. (2011) A New Keynesian Perspective on the Great Recession. Journal of Money, Credit and Banking 43: 31-54.

Ivashina, V. and D. Scharfstein (2010) Bank Lending During the Financial Crisis of 2008. Journal of Financial Economics 97: 319-338.

Iyer, R., J.-L. Peydró, S. da-Rocha-Lopes and A. Schoar (2013) Interbank Liquidity Crunch and the Firm Credit Crunch: Evidence from the 2007-2009 Crisis. Review of Financial Studies 27: 347-372.

Kydland, F. and E. C. Prescott (1990) Business Cycles: Real Facts and a Monetary Myth. Federal Reserve Bank of Minneapolis Quarterly Review Spring 14: 3-18.

Puri, M., J. Rocholl and S. Steffen (2011) Global Retail Lending in the Aftermath of the US Financial Crisis. Journal of Financial Economics 100: 556-578. 